\title{
The significance of philosophy in upbringing
}

\author{
Oleg S. Volgin ${ }^{1 *}$ and Elena $S$. Karsanova ${ }^{2}$ \\ ${ }^{1}$ Moscow State Institute of International Relations (MGIMO-University), School of Governance and \\ Politics, Department of Public Administration, Moscow, Russia \\ ${ }^{2}$ Financial University under the Government of the Russian Federation, Department of Political \\ Science, Moscow, Russia
}

\begin{abstract}
The article considers the issues of the upbringing significance of philosophy as a university discipline in forming a student's personality. This issue is caused by the specifics of philosophical knowledge, which, on the one hand, is not related to the specific professional needs of students, defined in the State Educational Standard as three goals: "to know - to be able - to master the skills", and, on the other hand, causes a positive response and interest in the majority of students. Young people find in philosophy something no less important than professional and practical knowledge. The authors draw attention to the latent upbringing role of philosophical knowledge. To this end, the authors separate the concepts of education and upbringing and show that while education, in general, is limited by the social demand, upbringing by its nature is not limited by the social framework and its purpose is to create conditions for forming a person. The authors prove that philosophy plays a deep upbringing role, as holistic knowledge that combines ontology, epistemology, ethics, aesthetics, and axiology. The article reveals the association between the idea of being with the need of a person to distinguish reality from pseudo-reality, actual spiritual and personal development from deceptive success, to determine for themselves the real rather than illusory goals of life.
\end{abstract}

Keywords: education, upbringing, personality, thinking.

\section{Introduction}

Is philosophy really necessary at the university as a basic course? Most often, students consider psychology to be a more important subject. Hence, the question arises whether philosophy should be replaced with psychology as the basic discipline of the State Standard while philosophy can be an optional discipline of the student's choice, as is the case in most foreign universities.

Such an idea seems unacceptable to the authors of the present study because philosophy should perform the most important upbringing function, which is formulated out in the Federal Law on Education, namely, to form the student's worldview. However, this is where the problem lies that teachers of philosophy are faced with and must solve for themselves. While in Soviet times upbringing meant giving a young person the only "true scientific worldview", today such an attitude to philosophy as an academic discipline is impossible and

* Corresponding author: oleg.volgin@gmail.com 
even morally unacceptable due to the increased differentiation of knowledge and the diversity of people's ethical attitudes. Philosophy itself does not allow to be treated as a means of upbringing if the latter is understood as the "inoculation" of a certain worldview. Such an attitude would be contrary to the free spirit of philosophy, which requires treating rational human beings as an end in themselves and not as a means to something else (I. Kant).

Besides, when talking about the worldview, one is entering on shaky ground, because the meaning of this concept is too general and vague. The content of the worldview includes the sensual, rational, and even mystical experience of the individual, not to mention the psychological, ideological, confessional, and other "vaccinations" that a person receives in society from an even unconscious childhood. Therefore, concerning philosophy, it is reasonable to say only that it has very limited impact on the worldview, and therefore on the person's upbringing.

\section{Methods}

It is impossible to perceive philosophy as a direct tool of upbringing for several reasons. First, upbringing is a delicate process. This process is not external, but internal, intimate, requiring a certain spiritual environment, which is possible only under the condition that, as K. Marx wrote, "the educator himself must be educated"[1]. But what are the objective standards of good upbringing?

Secondly, it is a dialogical process that requires communication on equal terms. In this regard, a teacher in his work should follow an attitude that he has no moral grounds to spiritually dominate over the student, and impose any worldview upon the student considered right from the standpoint of the mentor. The maxim of teachers' activity should be: 1) informing the student about philosophical ideas and teachings, and 2) rational argumentation of their statements, opinions, and theories. As for personal life experience and their beliefs, without a rational argument for a thinking audience, this information, although it contains a certain pedagogic potential, remains insignificant.

Third, it is a process with unpredictable consequences. In this case, upbringing should not be confused with education. While education gives an individual an image that is in demand by society, including intellectual, professional, and civic qualities, then the situation with upbringing is more complicated. In everyday speech, people are used to putting a constructivist meaning into the concept of upbringing. It is not without reason that the authors believe that the family, the school, and society shape a person in a certain sense. But these are only external sources of upbringing. Eventually, the determining factor of upbringing is the mysterious and inexplicable origin of a human personality, his individual self.

Upbringing is responsive since external factors are only conditions that cause certain responses of one's individual self. Nobody knows with certainty what these responses will be, so it is impossible to get a pre-determined result in the upbringing process.

The philosophy teacher gives the student certain information, discusses subject topics, reveals methods of cognition, and shares the personal experience. All this is nothing more than the necessary spiritual ingredients for the organic growth and development of the student's personality. The educator can pursue constructive goals concerning the student's personality, promote forming positive social qualities in his personality, spark interest in a certain kind of knowledge, form the ability to think creatively, etc. However, the result ultimately depends on the inner quality and potential of the student's personality, which are given to him by nature, rather than on the educator's efforts. All the efforts of the teacher are nothing more than the effort of growing this mysterious "seed" of the spirit, from which a human personality grows. Therefore, despite the self-confidence inherent in socio-centric pedagogy, which reduces the key role in upbringing to a social determinant, the authors recognize the fundamental limitations of external upbringing opportunities. The "self" as the 
core of the human personality is the most mysterious object in the surrounding world. It is equally hidden from one's perception and understanding, as well as from purposeful impact. The authors believe that despite the superflexibility of the human personality which can get used to almost everything, human has a certain atom of his "self", which does not allow "listening to good and evil indifferently". And the fact that, despite the innumerable victories of evil over good known in history, humanity still strives for good, suggests the truth of the words of V.S. Solovyov, that human intrinsically has the "inner disposition of his will to good" [2]. In this context, upbringing is a very correct word since it means the nourishment of this "atom" of good, which is the basis of the human personality.

\section{Results}

\subsection{Philosophy as the spiritual food of the individual}

When turning to the world educational experience, one will see a characteristic dependence: the popularity and demand for philosophy are directly related to the level of economic and humanitarian development of society in general. The higher this level is, the greater the public interest in philosophy is. And this is no coincidence. The development of personality, although it by its nature is an internal process, still requires favorable external conditions. Of all the types of rational knowledge that make up the university education curricula, philosophy has a special role. It aims to reveal what no particular field of knowledge can reveal - the world in its entirety, including the person himself in this integrity. In other words, philosophy allows one to see himself in this world, his place, opportunities, and responsibility. Plato called this the ability to turn a person's gaze inward. The educational significance of philosophy was briefly formulated by M.K. Mamardashvili: "Philosophy is an element of man's creation of himself" [3]. The growing influence of philosophy on the process of university education in recent years is also found in the increasing flow of publications by foreign researchers [4-12].

Certainly, this is not just about philosophical ethics, although its significance for university education as such cannot be overestimated. It would also be wrong to assume that the knowledge of ethical theories and the analysis of study cases on moral aspects are intrinsically sufficient for the parenting effect of philosophy on the individual.

Philosophy has the greatest influence on the formation of a person by the very way of thinking. Thinking is always an actual experience. Mamardashvili defined philosophy as "thinking aloud". But the thought is a thing difficult to define, eluding definitions. Therefore, to evaluate the educational potential of thought, it is necessary to separate it from what is not a thought. A thought is not a definition, a judgment, or even ratiocination. All these are forms of thought, its results but not the thought itself. The thought is elusive and spontaneous, it cannot be controlled; one cannot force himself to think by will. A thought is never produced, it always happens. When it happens, the surrounding reality disappears for a person; a person seems to immerge into an otherworldly existence, into that world of thought where there is no space and time. Plato has shown this by the example of the strange behavior of Socrates, who used to freeze in place and could stand motionless, as Alcibiades claimed, for about a day seized with a thought [13].

\subsection{Philosophy teaches to be}

The first and main task of philosophy is to continuously teach a person to be, exactly to teach continuously, rather than once and forever because it is impossible to learn to be once and forever. The individual learns to be in the course of his entire life. 
The very first familiarity with philosophy leads students to thought concerning the difference between being and its appearance, between life and apparent existence, actual and fake. According to Socrates, the dialectical thinking developed by philosophy releases, "as if from some barbaric mud, the gaze of our soul burrowed there gets a rise out of there and directs it upward" [14].

The issue of actual existence has always been the most important one for a human, especially today, when people have surrounded themselves with unprecedented information resources, and reproducing pseudovalues that have no relation to actual life. In this context, the need to turn the "eye of the soul" to reality becomes increasingly significant and demanded by society. The practice of seminars shows that the topic of actual life is one of the topics most discussed by students.

Everyone knows the wise saying "The truth speaks through the mouth of an infant." Not so much on reasonable grounds, but out of habit, philosophical thinking is referred to as a mature age, when a person has accumulated life experience, developed the ability for abstract thinking, has some idea of wisdom. Therefore, one turns to the thoughts of the great philosophers. However, nobody can specify the boundaries where philosophical consciousness begins to form. At that, it is worth to say that "pure" thinking is inherent exactly in children. Children see reality as it is, and it is not them, who are sleeping in the "dogmatic dream".

\section{Conclusion}

The main educational task of philosophy can be called its ability to return one to an essentially childish state of surprise at reality, and activate thinking about it, which allows uncovering the true meaning of life, and therefore actually be.

\section{References}

1. K. Marx, Tezisy o Feyyerbakhe [Theses on Feuerbach], in K. Marx, F. Engels, Sochineniya [Works], Volume 3 (Izdatelstvo politicheskoy literatury, Moscow, 1955)

2. V.S. Solovyov, Opravdaniye dobra [The justification of the good], in Sochineniya v 2 tomah [Works in 2 volumes], Volume 1 (Mysl, Moscow, 1990)

3. M. Mamardashvili, Lektsii po antichnoy filosofii [Lectures on Ancient Philosophy] (Klassika, Saint Petersburg, 2018)

4. G. Biesta, Educational Philosophy and Theory, 44(6), 581-593 (2012). https://doi.org/10.1111/j.1469-5812.2011.00783.x

5. M. Mason, Educational Philosophy and Theory, 40(1), 4-18 (2008). https://doi.org/10.1111/j.1469-5812.2007.00412.x

6. M.O. Webb, A.G. Karabaeva, I.M. Kuntuova, Procedia - Social and Behavioral Science, 174, 3847-3852 (2015). https://doi.org/10.1016/j.sbspro.2015.01.1123

7. G.H. Mead, The Philosophy of Education (Routledge, New York, 2016)

8. M. Peters, P. Ghiraldelli, B. Zarnic et al., Encyclopedia of Educational Philosophy and Theory (Springer, Singapore, 2016)

9. M.W. Meyer, D. Norman, She Ji:The Journal of Desing, Economic and Innovation, 6(1), 13-49 (2020). https://doi.org/10.1016/j.sheji.2020.07.004

10. N. Noddings, Philosophy of Education (Routledge, New York, 2018)

11. D.J. O'Connor, An Introduction to the Philosophy of Education (Routledge Library Educations, London, 2017) 
12. Y. Bayrak, Procedia - Social and Behavioral Science, 174, 2713-2715 (2015). https://doi.org/10.1016/j.sbspro.2015.01.956

13. Plato, Pir [Symposium], in Sobraniye sochineniy v 4 tomah [Collected works in 4 volumes], Volume 2 (Mysl, Moscow, 1993)

14. Plato, Gosudarstvo [Republic], in Sobraniye sochineniy v 4 tomah [Collected works in 4 volumes], Volume 3 (Mysl, Moscow, 1994) 